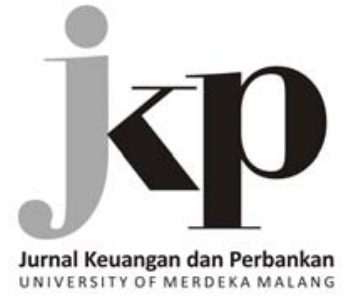

Article history:

Received: 2018-11-01

Revised: 2018-12-27

Accepted: 2019-01-30

\section{Keywords:}

Attitudes; Behavioral Control; Subjective Norms;

Whistleblowing Intention

JEL Classification: D23, G34, L23

Kata Kunci:

Sikap; Kontrol Perilaku; Norma

Subjektif; Whistleblowing

Intention

$\triangle$ Corresponding Author:

Tarjo:

Tel +62 87853035508

E-mail: tarjo@trunojoyo.ac.id

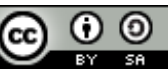

This is an open access article under the CC-BY-SA license

\section{Theory of planned behavior and whistleblowing intention}

\author{
Tarjo, Prasetyono, Anang Suwito, Ifa Diah Aprillia, \\ Greska Redielano Ramadan
}

Department of Accounting, Faculty of Economics and Business, University of Trunojoyo Madura Jl. Raya Telang PO BOX 2 Kamal Bangkalan Madura, 69162, Indonesia

\section{Abstract}

This research examined the theory of planned behavior (TPB) as predictor whistleblowing intention. According to TPB, it is difficult to posit whistleblowing as actual behavior. Whistleblowing is more suited to be posited as intention. Intent means the likelihood of actual behavior occurred. We examined attitude, subjective norms, and perceived behavioral control as TPB variables. We also investigated a few control variables such as colleagues support, organizational support, and fear of retaliation. The online survey was conducted in obtaining data by a web-based questionnaire. Participants of this survey were employees of regional owned east java bank. The number of respondents was 112 employees from all departments and units. Validity, reliability, regression, and path analysis were used in testing research instrument and several hypotheses. The result showed that attitudes and subjective norms as TPB variables have a significant impact on whistleblowing intention. However, perceived behavioral control does not affect whistleblowing intention. While, among several control variables, only fear of retaliation that has a significant effect on whistleblowing intention. Furthermore, this study also found empirical evidence that knowledge and subjective norms have an indirect effect on whistleblowing intention through attitudes. This research suggests that regional owned east java bank should provide an environment and channels to support whistleblowing within effectively, especially through protection and/or reward systems, or etc.

\section{Abstrak}

Penelitian ini menguji Theory of Planned Behavior (TPB) sebagai prediktor whistleblowing intention. Menurut TPB, sulit untuk mengungkap whistleblowing sebagai perilaku aktual. Whistleblowing lebih cocok untuk dianggap sebagai niat. Niat berarti kemungkinan perilaku aktual terjadi. Kami meneliti sikap, norma subjektif dan kontrol perilaku yang dirasakan sebagai variabel TPB. Kami juga meneliti beberapa variabel kontrol seperti dukungan kolega, dukungan organisasi, dan rasa takut akan pembalasan. Survei online dilakukan untuk mendapatkan data dari kuesioner berbasis web. Partisipan dalam survei ini adalah karyawan bank milik pemerintah daerah Jawa Timur. Jumlah responden adalah 112 karyawan dari semua departemen dan unit. Validitas, reliabilitas, regresi, dan analisis jalur digunakan untuk menguji instrumen penelitian dan beberapa hipotesis. Hasil penelitian menunjukkan bahwa sikap dan norma subyektif sebagai variabel TPB berpengaruh signifikan terhadap intensi whistleblowing. Namun, kontrol perilaku yang dirasakan tidak mempengaruhi niat whistleblowing. Sementara itu, sekitar beberapa variabel kontrol hanya takut akan pembalasan yang secara signifikan memengaruhi niat whistleblowing. Lebih jauh lagi, penelitian ini juga menemukan bukti empiris bahwa pengetahuan dan norma subyekt if memiliki efek tidak langsung terhadap niat whistleblowing melalui sikap. Penelitian ini menyarankan kepada bank milik pemerintah daerah Jawa Timur untuk mendorong lingkungan dan saluran untuk mendukung whistleblowing.

How to Cite : Tarjo, Prasetyono, Suwito, A., Aprillia, I. D., Ramadan, G. R. (2019). Theory of planned behavior and whistleblowing intention. Jurnal Keuangan dan Perbankan, 23(1), 45-60. https://doi.org/10.26905/jkdp.v23i1.2714 


\section{Jurnal Keuangan dan Perbankan}

Volume 23, Issue 1, January 2019: 45-60

\section{Introduction}

Based on the survey of fraud Report to The Nation, the majority of fraud cases can be detected by the existence of a tip (Association of Certified Fraud Examiners, 2018). One of the reporting forms on fraud cases is whistleblowing. Whistleblowing is the disclosure of an immoral, illegal, or other illegal act of an individual or group that is incorporated as a member of an organization, which in his capacity can take such actions (Near \& Miceli, 1985; Pillay et al., 2015). Whistleblowing includes several elements, namely whistleblowers, complaints or reports, reported parties, and authorized parties to follow up (Near \& Miceli, 1985).

Several issues regarding whistleblowing have arisen and become the concern of many parties, especially the intention to conduct whistleblowing. First of all, many types of research have stated that whistleblowing is an effective tool to uncover violations (Chang, Wilding, \& Shin, 2017). In addition, whistleblowing is able to encourage good governance, accountability, and transparency (Pillay et al., 2015). However, other research suggests that whistleblowing is not an easy thing to do (Mesmer-Magnus \& Viswesvaran, 2005; Latan, Jabbour, \& Jabbour, 2016; Chang, Wilding, \& Shin, 2017). Whistleblowers are always associated with negative consequences such as demotion, dismissal, and safety threats, even the "whistleblower" might become blacklisted (Miceli \& Near, 1988).

Secondly, a lot of researches claimed that pushing whistleblowing into actual behavior (applied) is still difficult. Whistleblowing can be seen from two perspectives, namely as intention and actual behavior (Chang, Wilding, \& Shin, 2017). Meanwhile, according to Ajzen (1991) to explain the actual behavior of individuals, what can be done is to identify the intention or tendency of individuals to display such behavior. Awang \& Ismail (2018) also said that to observe actual behavior is a highly tough thing to be done. Therefore, behavior can be identified by observing the potential of its occurrence. The intention is a predic- tor of actual behavior (Ajzen, 1991). Whistleblowing can be specifically identified through the intention to do so (Park \& Blenkinsopp, 2009).

We focus on predicting actual whistleblowing behavior through the tendency or intention in doing it. Research that aims to explain whistleblowing as an intention has been done by many before (MesmerMagnus \& Viswesvaran, 2005; Park \& Blenkinsopp, 2009; Richardson, Wang, \& Hall, 2012; Trongmateerut \& Sweeney, 2013; Chang, Wilding, \& Shin, 2017). Researches in predicting intention often used the two most distinguished psychological theories, namely the theory of reasoned action and theory of planned behavior. Chang, Wilding, \& Shin (2017) examined variables in the theory of planned behavior (TPB) as well as several control variables that were personal and contextual. The research proved that TPB variables are robust in explaining whistleblowing intentions.

The relation of TPB and whistleblowing intention goes beyond. Previous studies said that there is a contingent effect of TPB variables. Erikson \& Fallan (1996) and Trongmateerut \& Sweeney (2013) said that attitudes naturally is intervening/mediating variables. They argued that an individual's attitudes could be influenced by their knowledge and people's opinions where they rely on it. Attitudes can be shaped by an individual's knowledge about certain things. Knowledge can be achieved through education, experience, and many other way. Erikson \& Fallan (1996) conducted experimental studies and conclude that taxpayer compliance arises when taxpayer knowledge increase. Then, the research of Trongmateerut \& Sweeney (2013) tested variables in the theory of reasoned action (TRA) to predict whistleblowing intentions. This research found indirect effects of subjective norms on whistleblowing intentions through attitudes to whistleblowing. The research showed that there is a relationship between subjective norms and attitudes. They said that individual attitudes could determine how the influence of the referent person and/or referent group. Individual attitudes can be shaped by indi- 
vidual or group opinions that he/she relies on it. Individual attitudes can be shaped by internalizations and identification process. Previous research has been proving this relation empirically (Bock et al., 2005; MesmerMagnus \& Viswesvaran, 2005; Trongmateerut \& Sweeney, 2013; Lewis, Agarwal, \& Sambamurthy, 2014). The prediction of whistleblowing intentions also shows the existence of multi-level variables may indicate a contingent relationship (Latan, Jabbour, \& Jabbour, 2016).

Several previous studies on whistleblowing intention are still unclear in examining the contingent nature of attitudes. We are interested in reexamining variables in TPB as predictors of whistleblowing intentions. We argue that TPB more complete than TRA in the term to explain intention. TPB was broader than TRA. We also tested the indirect relationship of each of these variables, which had not been done in previous studies. We added knowledge to be a factor affecting attitudes as an extension of contingent nature. In addition, the previous researches identified predictors of whistleblowing intention in public sectors and social organizations. Meanwhile, referring to some of the previous research, there were not many kinds of research related to whistleblowing intentions in the banking industry. Based on research by Awang \& Ismail (2018), employees who play a role in the financial reporting process in banks in Malaysia showed a high intention to commit fraud.

We determined Regional Owned East Java Bank called ZZZZ Bank as our object studies. We considered this company to be our research object because of still many cases of irregularities on those place. We got this information from one of our research team members is ZZZZ Bank employee. According to the current data collected by our team member, during 2018 internal control unit of ZZZZ Bank have found 17 cases of wrongdoing/ fraud indication. The number of cases found in 2018 is 44 percent from the last three years prior. During 2016-2018 the number of cases that found around is 38 cases. Most of the cases discovered from a report by the internal control unit of ZZZZ Bank. However, from all cases founded in 2018 , only 1 case reported by the employee. This number of employee reporting indicates that employee participation in reporting wrongdoing or blowing the whistle is very poor. ZZZZ Bank has been implemented whistleblowing as a tool of fraud detection, but it still doesn't systematically. We considered this condition in order to understand the individual and situational process of the intention to blow the whistle among ZZZZ Bank employee.

Thus, this research tries to explore and predict the whistleblowing intentions of banking employees. The prediction of whistleblowing intentions in this research also examines several situational variables. Some situational variables are intended to test hypotheses that individuals will only do whistleblowing under certain conditions (Hwang et al., 2008; Park \& Blenkinsopp, 2009; Cassematis \& Wortley, 2013; Trongmateerut \& Sweeney, 2013; Cho \& Song, 2015; Chang, Wilding, \& Shin, 2017). Several situational variables which included in the models such as colleagues support organizational support and fear of retaliation. This research contributes to several things. First, we contribute to extending previous studies to investigating the contingent nature of attitudes. We contribute to developing a model with robust variables from previous research with different contexts, which is the banking sector. We are also extending the models that differ from prior research. We add knowledge in the models and examine it variable as a direct and exogenous variable. Then, we also contribute to the term to posses attitudes as contingent variables. This study is a pilot project in Regional Owned East Java ZZZZ Bank. Then, we fill the lack of whistleblowing studies in the banking industry.

\section{Hypotheses Development}

This research uses TPB as a predictor of whistleblowing intentions. TPB is the development of TRA. Both TRA and TPB have been widely used as predictors of actual behavioral and behavioral intentions (Madden, Ellen, \& Ajzen, 1992). TRA contains 


\section{Jurnal Keuangan dan Perbankan}

Volume 23, Issue 1, January 2019: 45-60

two constituents, namely attitudes (attitude toward behavior) and subjective norms (Trongmateerut $\&$ Sweeney, 2013).

Meanwhile, TPB expanded its intention predictors by adding a third factor, namely behavioral control (Ajzen, 1991). TPB can be used as a prediction of whistleblowing intentions because actual intention and behavior contain complex psychological processes (Gundlach, Douglas, \& Martinko, 2003). TPB provides an explanation that the three factors mentioned before can affect the intention of individual behavior (Ajzen, 1991). The TPB's predictors have a role in shaping individual intention to perform a specific behavior. These three factors are a function of behavior and being a belief related to the process to perform some behavior.

Logically because the individual's attitude towards certain behavior (whistleblowing) is based on his/ her knowledge of the behavior, we also suspect that attitudes are influenced by knowledge. Based on several previous research, we suspect that attitude is mediating variables. It has a contingent nature that appears indirect effect between knowledge, attitudes and whistleblowing intention (Bock et al., 2005; MesmerMagnus \& Viswesvaran, 2005; Trongmateerut \& Sweeney, 2013; Lewis, Agarwal, \& Sambamurthy, 2014; Latan, Jabbour, \& Jabbour, 2016). The positive attitude of individuals towards whistleblowing is influenced by individual knowledge about whistleblowing. Erikson \& Fallan (1996) said that their knowledge about those certain things could shape individuals attitudes about something. Knowledge can be obtained through education or experience. When people know whistleblowing, the cognitive process can be increased. They can understand the nature of whistleblowing. This understanding has a role in the evaluation process to decide to blow the whistle or not. This argument gives us an understanding of how the relationship between knowledge and attitudes. The more peoples know whistleblowing, the more they consider to do this. When management gives understanding to the employee about the importance to report wrong- doing, they can arise the employee mind inclusions about whistleblowing. Erikson \& Fallan (1996) give empirical evidence that knowledge can affect individuals attitude. According to that explanation, we hypothesized that knowledge could affect whistleblowing intention through attitude. We develop the mediating hypothesis below:

$\mathrm{H}_{1 \mathrm{a}}$ : knowledge affect whistleblowing intention through attitude positively

$\mathrm{H}_{1 \mathrm{~b}}$ : knowledge on whistleblowing has a positive effect on the intention to do whistleblowing

The element of attitude referred to here is an understanding of the consequences of an action. This understanding will bring an individual to consider how far he will agree or not agree on certain behavior. In short, the individual will only act when he knows the logical consequences of an action. Attitudes towards whistleblowing will be created based on individual considerations/evaluations regarding the good/ bad consequences that will be received after doing whistleblowing. When an individual believes that whistleblowing will only have an adverse effect on him, he will tend to be reluctant to do whistleblowing.

Conversely, when an individual assesses whistleblowing is a positive thing for him, then he will tend to do whistleblowing. Previous research has shown that attitudes show a significant positive influence on whistleblowing intentions (Park \& Blenkinsopp, 2009; Trongmateerut \& Sweeney, 2013; Chang, Wilding, \& Shin, 2017). Thus, we develop the following hypothesis:

$\mathrm{H}_{1 \mathrm{c}}$ : attitudes have a positive influence on the intention to do whistleblowing

Attitude not only influenced by an individual's knowledge but also it can be affected by the opinions of important referent about certain behavior (Cialdini \& Goldstein, 2004). Ryan (1982) stated that attitude and subjective norms are highly correlated. Norms have a role in determining an individual's belief about cer- 
tain behavior whether it accepted or not in a certain social environment. Lewis, Agarwal, \& Sambamurthy (2014) explained that an individual's attitude toward whistleblowing also depends on their internalization and identification process of referent opinions. The more whistleblowing is accepted in the social environment, and important persons indicate the same opinions, the more individuals tend to blow the whistle. $\mathrm{He} /$ she suppose that reporting wrongdoing is expected behavior in their community and also justified by their referent persons. Their attitude will be shaped by their important referent (Bock et al., 2005; Mesmer-Magnus \& Viswesvaran, 2005; Trongmateerut \& Sweeney, 2013; Lewis, Agarwal, \& Sambamurthy, 2014). Then, when individuals think that reporting wrongdoing is acceptable behavior or expected behavior, they may consider this as a consequence. Being accepted by their important referent is a positive purpose. So, they more likely to blow the whistle, because it can give positive implication for them. We suspect that attitude toward whistleblowing is mediated the relationship between subjective norms and whistleblowing intention. Previous research has been proving it empirically (Bock et al., 2005; Mesmer-Magnus \& Viswesvaran, 2005; Trongmateerut \& Sweeney, 2013; Lewis, Agarwal, \& Sambamurthy, 2014). The explanations above bring us to this hypothesis:

$\mathrm{H}_{2 \mathrm{a}}$ : subjective norms have a positive effect on the attitude toward whistleblowing

The second element of TPB is subjective norms. Subjective norms definitively mean individual interpretations of the opinions of others about certain behavior (Park \& Blenkinsopp, 2009). Individuals live in certain communities in certain environments. In a community, there are usually certain things that are agreed upon so that doing or not doing something can make an individual accepted in that community. Or maybe vice versa, individuals will be excluded from the community. Norms play a role in influencing a person's behavior because it clarifies certain behaviors expected by oneself and a community (subjective norms) (Cialdini \& Goldstein, 2004). When a referent group has an opinion or indirectly agrees to do whistleblowing, then individuals who are members of the social group will tend to do whistleblowing. Especially when there are influential individuals in a social group, the group members tend to agree and act according to the referent figure (Bobek, Roberts, \& Sweeney, 2007; Feldman \& Lobel, 2007). Previous researches which show that subjective norms can be predictors of whistleblowing intentions are MesmerMagnus \& Viswesvaran (2005), Park \& Blenkinsopp (2009), and Trongmateerut \& Sweeney (2013). However, some research also shows the contingent nature of the relationship between subjective norms and attitudes. The argument is that individual attitudes can be formed by subjective norms in a group (Ryan, 1982; Bock et al., 2005; Albrecht \& Carpenter, 2010). The referent individuals or groups opinions about certain things will internalize and identified by the member of groups. It can affect their attitude about these certain things. The opinions will be a consideration to evaluate how certain action is favorable or unfavorable. Based on the flow of the theoretical framework, the hypotheses can be developed as follows:

$\mathrm{H}_{2 \mathrm{~b}}$ : subjective norms have a positive effect on the whistleblowing intention

The next predictor is perceived behavioral control. Ajzen (1991) stated that behavioral control is related to individual perceptions about whether it is easy or not to do a behavior. This perception is related to the element of resources and the opportunity to take action (Park \& Blenkinsopp, 2009). This third factor can be in the form of attributes, as in manifestations of behavioral control, such as the experiences of other people or individuals related to a matter, then other factors such as the existence of resources such as protection and so on. When resources and opportunities support individuals to do whistleblowing, individuals will tend to do whistleblowing. Some researches that proved that behavioral control is a robust factor in explaining whistleblowing intentions are Park \& 
Blenkinsopp (2009) and Chang, Wilding, \& Shin, (2017). Based on the theoretical framework, we formulated the following hypothesis:

$\mathrm{H}_{3}$ : perceived behavioral control has a positive effect on whistleblowing intention.

In this research, we also tested several control variables, such as the support of colleagues, organizational support and fear of retaliation. Some of these control variables are adapted from previous researches in Miceli \& Near (1988), Mesmer-Magnus \& Viswesvaran (2005), Pillay et al., (2015), and Chang, Wilding, \& Shin (2017). Support from colleagues factor was identified by the parameters of the support of close people to do and agree on whistleblowing be carried out. Then, the organizational support factor is identified by the encouragement and appreciation of the organization for the whistleblowing. Meanwhile, the fear of retaliation leads to the threat of negative actions from various parties that might be related.

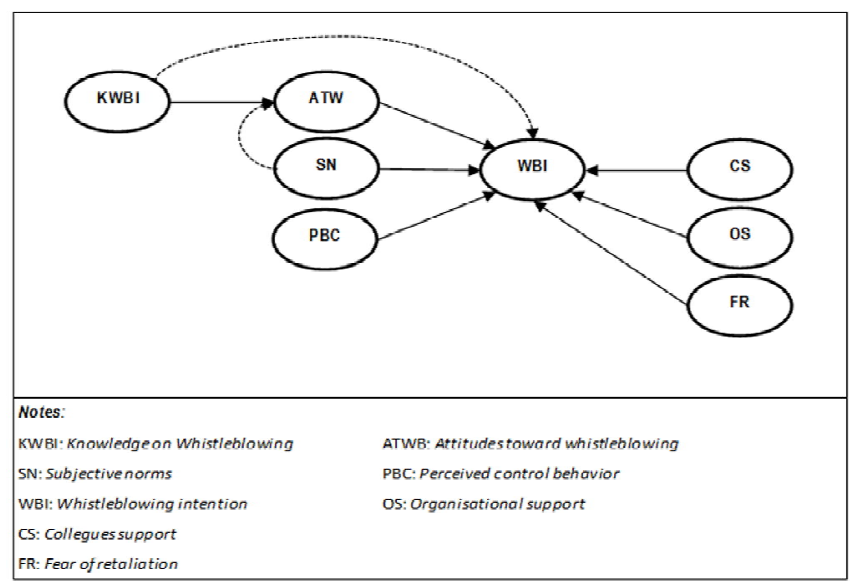

Figure 1. Conceptual Framework

\section{Method, Data, and Analysis}

This study used a quantitative approach. Data collection was done by using survey techniques by distributing questionnaires to respondents. The respondents of this study were employees of ZZZZ Bank, one of the Regional Owned Enterprises (BUMD) in East Java. ZZZZ Bank was positioned as a research object by considering the number of reports of irregularities such as procedural violations, assets misappropriation (especially credit assets), and other forms of irregularities. This report was obtained from a member of the research team who is an employee of the Internal Supervisory Unit (SPI) at ZZZZ Bank. All employees of the ZZZZ Bank East Java were determined as population. For the research sample, we used simple random sampling techniques through voluntary participation. The questionnaire was distributed online to all employees of Bank ZZZZ East Java. The number of samples was determined using the Slovin formula because the population is known. The total number of members of the population were 1114 employees of Bank ZZZZ East Java. The results of the calculation of the sample number using the Slovin formula was 92. Meanwhile, the results of distributing online questionnaires with voluntary participation gained 112 participant responses. However, there are some responses that cannot be processed because of their incomplete reasons so that the final data that can be processed is 100 data.

Regarding research instruments, we referred to the design of the instruments used by the research of Park \& Blenkinsopp (2009), Trongmateerut \& Sweeney (2013), Cho \& Song (2015), Pillay et al. (2015), and Chang, Wilding, \& Shin (2017). We used multiple item measures for one construct/variable. Each variable consisted of 4 to 5 statement items that had been adapted and modified from several studies mentioned earlier. We used this design in consideration of the simplification of research instruments. Generally, survey-based research often gets a low response, particularly in online-based research using web-based surveys. This can be due to the design of complex research instruments and contains many question items. Therefore, simplification of instrument design can be an alternative to improve the response of research respondents (Christophersen \& Konradt, 2011). Furthermore, Christophersen \& Konradt (2011) stated that the multiple-item measure owns good validity and reliability. 
This research adopted statement items from single-item measure concept of Chang, Wilding, \& Shin (2017) as the main item. Then, we modified the single-item by adding statement items from Park $\&$ Blenkinsopp (2009), Trongmateerut \& Sweeney (2013), Cho \& Song (2015), and Pillay et al. (2015). The addition of items was intended to test the consistency of respondents' answers. This was purposed to maintain the validity and reliability of the instrument. In addition, the addition of items was also intended to anticipate the possibility of the cancellation of the statement because of its inadequate validity and reliability.

Independent variables and measurements used in this study were knowledge on whistleblowing measured by the main statement "I understand the procedure and have sufficient knowledge about whistleblowing"; attitudes (toward whistleblowing) measured by according to two indicators, first the individual understanding about the consequences of his/ her whistleblowing and the importance of consequences toward their personal life. We measure attitudes with the statement "In general, I support whistleblowing at ZZZZ Bank"; subjective norms are measured by the statement in which derived from two indicators, which are a person's thought about the importance of approval or disapproval from the referent persons of individual whistleblowing and the respondents motivations to comply with the expectations of the referent. Subjective norms measured by this statement, "My colleagues will strongly approve the whistleblowing that I do"; about perceived behavior control, we derived the question from this indicator, which is individual perceives about difficulties in performing the behavior. The primary question to measure this third element of TPB is "Resources and opportunities to conduct whistleblowing in the company where I work are available"; colleagues' support is measured by the statement "Colleagues in my place work to support whistleblowing"; organizational support, "The company where I work strongly supports whistleblowing"; fear of retaliation, "I am afraid of retaliation for the whistleblowing that I did". Mean- while, the dependent variable is the intention to conduct whistleblowing as measured by the statement "I intend to report when there is a deviation in the company where I work." Then, we added some statement items that point to the previous main items.

To measure the respondent's response preferences, we use a Likert scale with intervals 1-4, which are; strongly disagree, disagree, agree, and strongly agree. We deliberately omit the middle/ neutral interval to avoid biased responses (Weijters, Cabooter, \& Schillewaert, 2010). This alternative was intended to stimulate the cognitive process of respondents to choose optimal answers (Krosnick, Narayan, \& Smith, 1996). Regarding the issue of the interval of answers/ responses, Lozano, García-Cueto, \& Muñiz (2008) stated that the optimal response interval is between four and seven.

\section{Results}

Data analysis in this study uses linear regression analysis and path analysis. The software used is SPSS. Data analysis in this research consists of several stages. First, by testing the validity and reliability of research instruments. Second, by testing classical assumptions. Path analysis and the ordinary least square (OLS) model do not escape from the classic assumption inherent. Therefore, some requirements of classical assumptions such as normality, multicollinearity, and heteroscedasticity must be fulfilled so that data can be further processed. Third, testing hypotheses using multiple linear regression analysis and path analysis. Path analysis using SPSS has the advantage of simple indirect influence testing models. In addition, the ease of analysis is offered by using this model and test equipment (Preacher \& Hayes, 2004). From the results of the online survey, 100 data could be processed. The demographic characteristics of the respondents were described by sex, marital status, recent education, position and length of employment. The majority of respondents were male with a percentage of 60.4 percent. In terms of marital status, the majority of respondents were married, with a percentage of 78.1 
percent. The last education of most respondents was undergraduate with a percentage of more than 80 percent. The length of work period of the majority respondents is between 1-5 years with a percentage of 45.8 percent, followed by respondents with a working period of 6-10 years, and 12.1 percent of respondents who have worked for 16-20 years. In terms of position or duty, the most part is from the audit section with a percentage of 32.7 percent, followed by 16.3 percent of the marketing department, 15.4 percent of the credit section, and 10.6 percent of each for the human resource department (HRD) and finance.

Descriptive statistics from research data are presented in Table 1. The results of descriptive statistical tests show respondents' answers to knowledge variables (KWB), subjective norms (SN), behavioral control (PBC), peer support (CS), organizational support (OS), and fear of retaliation (FR) are at 2.78 in average. These results indicate that the majority of respondents tend to have an answer preference that does not agree to some of these variables. Meanwhile, for attitudinal variables (ATB) and intention to conduct whistleblowing (IWB) showed an average rating of 3.14. This number indicates that respondents have a preference to agree on attitudes regarding whistleblowing and intention to do so.

Table 1. Descriptive Statistics

\begin{tabular}{lccc}
\hline \multicolumn{1}{c}{ Variabel } & Interval & Mean & Std. \\
\hline Knowledge (KWB) & $1-4$ & 2.9040 & 0.40043 \\
Attitude (ATB) & $1-4$ & 3.2182 & 0.44821 \\
Subjective Norms (SN) & $1-4$ & 2.8141 & 0.42306 \\
$\begin{array}{l}\text { Perceived Behavioural } \\
\text { Control (PBC) }\end{array}$ & $1-4$ & 2.8990 & 0.44306 \\
$\begin{array}{l}\text { Colleague Supports (CS) } \\
\text { Organizational Supports }\end{array}$ & $1-4$ & 2.9646 & 0.37798 \\
(OS) & $1-4$ & 2.7677 & 0.48478 \\
Fear of Retaliation (FR) & $1-4$ & 2.3409 & 0.59489 \\
Intention to do & & & \\
Whistleblowing (IWB) & $1-4$ & 3.0808 & 0.48554 \\
\hline
\end{tabular}

Then, the following table shows the result of testing the validity and reliability of research instruments. Based on Table 2, the research instrument was declared valid. The average value of $r$ count of all state- ment items is greater than the $r$ table value which is 0.1966 . These results indicate that statement item submitted to respondents in order to measure constructs/ variables under study can describe the construct.

Table 2. Instrument Validity

\begin{tabular}{lcc}
\hline \multicolumn{1}{c}{ Variable } & R Count & Note \\
\hline Knowledge (KWB) & 0.779 & Valid \\
Attitude (ATB) & 0.791 & Valid \\
Subjective Norms (SN) & 0.765 & Valid \\
Perceived Behavioural Control (PBC) & 0.723 & Valid \\
Colleague Supports (CS) & 0.719 & Valid \\
Organizational Supports (OS) & 0.737 & Valid \\
Fear of Retaliation (FR) & 0.840 & Valid \\
Intention to do Whistleblowing (IWB) & 0.800 & Valid \\
\hline Items are valid when calculated r value upper than 0,1996; Sig. 1\%, 5\%, \\
10\%
\end{tabular}

Next, the results of the test of the reliability of the respondents' answers are presented in Table 3. In Table 3 the Cronbach alpha value for all variables shows a greater number than 0.7 . These results indicate that the respondents' answers to the statement item for all variables are declared reliable. Respondents' answers were stated to be consistent over time.

Table 3. Reliability Analysis

\begin{tabular}{lcc}
\hline \multicolumn{1}{c}{ Variable } & $\begin{array}{c}\text { Cronbach } \\
\text { Alpha }\end{array}$ & Note \\
\hline Knowledge (KWB) & 0.870 & Reliable \\
Attitude (ATB) & 0.899 & Reliable \\
Subjective Norms (SN) & 0.878 & Reliable \\
Perceived Behavioural Control & & \\
(PBC) & 0.814 & Reliable \\
Colleague Supports (CS) & 0.811 & Reliable \\
Organizational Supports (OS) & 0.820 & Reliable \\
Fear of Retaliation (FR) & 0.917 & Reliable \\
Intention to do Whistleblowing & \multicolumn{2}{c}{} \\
(IWB) & 0.884 & Reliable \\
\hline Item is reliable when Cronbach alpha value upper than 0.7 &
\end{tabular}

Item is reliable when Cronbach alpha value upper than 0.7

The next stage of data analysis is the classic assumption test. Based on the test results of the classic assumptions of normality, multicollinearity, and heteroscedasticity, the research data tested in the model was declared to be eligible. Research data is declared normal based on the value of Asymp. Sig. 2-tailed above 0.05 which is equal to 0.951 . The multicollinearity as- 
sumption also shows that the data meets the criteria for this assumption. The identified model reveals no multicollinearity occurred based on the variance inflation factor (VIF) value below 10 and the tolerance value above 0.1 . The VIF score of all independent variables which are 1.910, 1.862, 2.252, 1.568, 2.116, 2.113, and 1.511. Heteroscedasticity analysis shows that the plot distribution is spread; it indicates that the model doesn't meet the criteria for this assumption.

The last data analysis is hypothesis testing. The results of hypothesis testing with model 1 show that the variable attitude (ATB), subjective norms $(\mathrm{SN})$ and fear of retaliation (FR) show a significant influence on the intention to do whistleblowing (IWB). While other variables are declared not influential. Furthermore, subjective attitudes and norms show a positive influence on the intention to do whistleblowing. Meanwhile, the variable fear of retaliation shows a negative influence. Table 4 shows the significance values of the three variables which are stated to have significant influence. These three variables show numbers that are smaller than the significance level of 1 percent, 5 percent, and 10 percent.

We also examine the indirect effects of knowledge variables (KWB) and subjective norms (SN). According to Ryan (1982), Bock, Zmud, Kim, \& Lee (2005), and Albrecht \& Carpenter (2010), there is a nature of contingencies from knowledge variables and subjective norms towards the intention to do whistleblowing through attitude. The results of the hypothesis test for the second model prove that the indirect effects of the two variables exist. The significance value of the two variables shows a number smaller than the significance level of 1 percent, 5 percent, and 10 percent. Table 5 shows the results of the second model test.

Knowledge variable has an indirect influence on the intention to do whistleblowing, which is through attitude. The first model test proves that the knowledge variable does not affect the intention to do whistleblowing. Rejection of the hypothesis for the knowledge variable in the first model reinforces the nature of contingencies of attitude variable. In the second model, it is proven that whistleblowing intention can be determined by attitude, while attitude can be explained by individual knowledge.

The nature of the contingency in attitude is also explained by subjective norm variable. The results of the second model test exhibit empirical evidence that subjective norm variables influence attitudes. Subjective norms can be a predictor of intention to conduct whistleblowing either directly (model 1), or indirectly through attitude. The results of this research prove that individual attitudes can be determined by subjective norms.

Table 4. Partial Test Model 1

\begin{tabular}{lccc}
\hline \multicolumn{1}{c}{ Variable } & Beta Co-efficiency & Significance & Note \\
\hline Knowledge (KWB) & 0.019 & 0.512 & Non influential \\
Attitude (ATB) & 0.125 & 0.000 & Significant influence \\
Subjective Norms (SN) & 0.042 & 0.083 & Significant influence \\
Perceived Behavioural Control (PBC) & 0.020 & 0.416 & Non influential \\
Colleague Supports (CS) & -0.300 & 0.366 & Non influential \\
Organizational Supports (OS) & -0.017 & 0.508 & Non influential \\
Fear of Retaliation (FR) & -0.036 & 0.043 & Significant influence \\
\hline
\end{tabular}

Significance Level: 1\%; 5\%; 10\%

Table 5. Partial Test Model 2

\begin{tabular}{lccc}
\hline \multicolumn{1}{c}{ Variable } & Beta Co-efficiency & Significance & Note \\
\hline Knowledge $(\mathrm{KWB})$ & 0.556 & 0.000 & Significant \\
Subjective Norms $(\mathrm{SN})$ & 0.373 & 0.000 & Significant \\
\hline
\end{tabular}

Significance Level: 1\%; 5\%; 10\% 
By using path analysis, we also compare the robustness of the first model with the second model. In the first model, the beta value for the effect of the knowledge variable on the intention to do whistleblowing is 0.019 . For the attitudinal variable, the beta value of the effect shown is 0.125 . Meanwhile, the beta value for the norm variable, the influence of subjective norms on intention to conduct whistleblowing is 0.042 . In the second model, the beta value of the effect of the knowledge variable on attitudes is 0.556 . Next, the beta value of the subjective norm variable in the second model is 0.373 . Path analysis compares the robust level of model 1 to model 2 . Path analysis is done by multiplying the beta value of the relationship between independent and intervening variable with a beta value of the relationship between intervening and dependent variable (in this case variable Z).

Table 6. Path Analysis

\begin{tabular}{lccc}
\hline \multirow{2}{*}{ Variables } & \multicolumn{2}{c}{ Coefficient Beta } \\
\cline { 2 - 4 } & Model I & Model II & Path Model \\
\hline KWB-WBI & 0.019 & & \\
ATB-WBI & 0.125 & & \\
SN-WBI & 0.042 & & \\
KWB-ATB & & 0.556 & 0.070 \\
SN-ATB & & 0.373 & 0.047 \\
KWB-ATB-WBI & & \multicolumn{2}{c}{} \\
SN-ATB-WBI & & \\
Path model is significance when beta value upper than the \\
model I
\end{tabular}

The beta value of the influence of knowledge variable through the attitude variable is 0.556 , multiplied by the beta value of the influence of attitude toward the intention to do whistleblowing which is 0.125 . The results of the multiplication obtain some 0.070. This number then added to the beta value, the direct effect of knowledge on the intention to do whistleblowing, which is 0.019 . The results of these calculations obtain the final number of 0.089 ; this score is the total effect of both models (direct and indirect effect). Path score for contingent effect between knowledge, attitude and intention to blow the whistle is 0.070 which is stronger than 0.019 (direct effect).
This result implies that the indirect influence of the knowledge variable is greater than the direct influence on the intention to do whistleblowing.

In addition, the beta value of subjective norms variable toward whistleblowing intention is 0.042 . While the beta value of the effect of subjective norms toward attitude is 0.373 , this number also multiplied with the beta value of the influence of attitude toward whistleblowing intention. This multiplication produces the path value of subjective norms, attitude and whistleblowing intention which is 0.047 . If it is added to the beta value of the direct effect of subjective norms toward whistleblowing intention resulted in a total score of 0.089 . The path calculation for the indirect effect of subjective norm through attitude toward whistleblowing intention gives greater value than the direct effect $(0.047>0.042)$. This result proves that the indirect influence of subjective norms through attitudes toward intention to do whistleblowing is stronger than the direct influence. Comparison of model 1 and model 2 shows that model 2 has a higher robust level compared to model 1 . This result also reinforces the argument that there is a contingent nature attached to the relationship between attitudes, subjective norms and intention to conduct whistleblowing.

Table 7. Determinantion Coefficient

\begin{tabular}{lcc}
\hline \multicolumn{1}{c}{ Description } & Adjusted R Square & $\%$ \\
\hline Model I & 0.525 & $53 \%$ \\
Model II & 0.437 & $44 \%$ \\
\hline
\end{tabular}

Statistically, the data demonstrate that variables of attitude, subjective norms and fear of retaliation are robust factors in explaining the intention to do whistleblowing. The intensity of influence (coefficient of determination) shown through the adjusted $\mathrm{R}$ square value of model 1 is equal to 0.525 or 53 percent. This means that the seven variables can explain the intentions of whistleblowing by 53 percent, while the remaining 47 percent is influenced by other variables that are not examined. 
The coefficient of determination for the second model is 0.437 or 44 percent. That implies the variables tested in the second model, knowledge and subjective norms, are capable of explaining the attitude variable by 44 percent. The rest, which is equal to 56 percent, might be explained by other variables beyond the model studied.

\section{Discussion}

The statistical assessment results show that the two of Theory of Planned Behavior variables can explain the intention to do whistleblowing (IWB). Attitude variables (ATB) and subjective norms (SN) show a positive influence on the intention to do whistleblowing. However, the third, a predictor of behavioral control (PBC) did not affect the intention to do whistleblowing. We also found that from among all control variables, only the variable fear of retaliation (FR) is able to be a predictor of whistleblowing intentions. In this research, we also obtained empirical evidence that supports the nature of contingencies from the attitude variable. By the second model test, it was found that attitudinal variable was influenced by knowledge (KWB) and subjective norms. Knowledge and subjective norms show a positive influence on attitudes. Therefore, hypotheses $1 \mathrm{a}, 1 \mathrm{c}, 2 \mathrm{a}$, and $2 \mathrm{~b}$ are declared affirmed.

Attitudes and subjective norms show a significant positive influence as predictors of whistleblowing intentions. Firstly, positive attitude towards whistleblowing can increase the intention to do so. The results of this research indicate that whistleblowing intentions increase when individuals show a positive attitude towards whistleblowing. Attitudes lead to one's understanding of the consequences of actions taken (Ajzen, 1991; Park \& Blenkinsopp, 2009). Based on attitude in the context of TPB, a person will only take certain actions when he/she understands the consequences of these actions. The consequences of the action will be a consideration for individuals whether to take certain actions or not. As stated earlier, many types of research suggested that whistleblowers are often as- sociated with negative impacts as a logical consequence of the whistleblowing that they do (Near \& Miceli, 1985; Miceli \& Near, 1988). As a result, the employee may be reluctant to do the whistleblowing because these actions are considered to only have a negative impact on them (Park \& Blenkinsopp, 2009). This stigma (knowledge) has implications for the individual's negative attitude toward whistleblowing. This research proves ZZZZ Bank employee has a positive view about whistleblowing. They have the intention to report wrongdoing. Unfortunately reporting participation by ZZZZ Bank employee is very poor. Management must build an environment that encourages the employee to blow the whistle. The effort can be done in several ways such as reward systems, promotion, or reinforce of code ethics compliance. Therefore, in order to encourage the employee to conduct whistleblowing when they find indications of irregularities, debriefing about the benefits of whistleblowing must be done. Debriefing can be in the form of providing education, training, protection, appreciation and so on. Thus, individuals will acknowledge that whistleblowing is a positive action. This research supports the research findings of Park \& Blenkinsopp (2009), Trongmateerut \& Sweeney (2013), and Chang, Wilding, \& Shin (2017).

The next one is how subjective norms are showing a positive impact on whistleblowing intentions. The intention to do whistleblowing will increase when the subjective norms that apply in a group agree on this. Subjective norms discussed things agreed upon by individuals in a group (Ajzen, 1991; Cialdini \& Goldstein, 2004; Trongmateerut \& Sweeney, 2013). Based on TPB, individual behavior can be influenced by subjective norms that apply to a group (Cialdini $\&$ Goldstein, 2004). Individuals will only take certain actions when the action is deemed appropriate and is expected to arise in a group. In social life, individuals are faced with social situations in which they are expected to respond according to what is agreed upon by the group. Subjective norms are part of social norms (Cialdini \& Goldstein, 2004). Norm itself plays a role in clarifying whether the behavior is expected or not 


\section{Jurnal Keuangan dan Perbankan}

Volume 23, Issue 1, January 2019: 45-60

expected to emerge from an individual. The results of this research prove empirically that when a group is committed to creating whistleblowing decision, the individuals inside it also tend to take the same action. Subjective norms can be labeled to be situational factors (Mesmer-Magnus \& Viswesvaran, 2005). Based on these findings, we conclude that it is important for the entity to establish a cooperative environment in reporting irregularities.

We know that the banking industry is highly regulated. The environment can be formed by creating situations and conditions in which all members are aware of indications of irregularities. Not only at the conscious level, but also create situations and conditions for civilization to prevent irregularities from happening and for example, encouraging employees to report indications of irregularities found in channels or authorized authorities. This can be done by emphasizing compliance with the code of ethics, regulations, and the standard operating procedure (SOP). So that employees realize that disclosing irregularities is a shared responsibility. When a group feels that it is important for them to do whistleblowing, the individuals in the group also show the same tendency. Feldman \& Lobel (2007) even stated that social norms are more effective in shaping behavior (whistleblowing intentions) than regulations. Our research findings support the results of research by Mesmer-Magnus $\&$ Viswesvaran (2005), Park \& Blenkinsopp (2009), and Trongmateerut \& Sweeney (2013).

Additionally, among the control variables, only the variable fear of retaliation (FR) shows an influence on whistleblowing intentions. The variable fear of retaliation shows a negative influence. That is, the intention of the whistleblowing will be lower when individuals are afraid of retaliation later on. As stated in the beginning, whistleblowers are often associated with negative impacts such as dismissal, violations, boringness, and other negative impacts. This is what makes individuals reluctant to do whistleblowing (Mesmer-Magnus \& Viswesvaran, 2005; Cassematis \& Wortley, 2013; Chang, Wilding, \& Shin, 2017).
Individuals may have knowledge and attitudes that whistleblowing is important, but that understanding has not reached the level of behavior. Or maybe the individual understands the importance of whistleblowing but is reluctant to do so because of the possible negative impact he might suffer. We obtained findings that are consistent with some previous research from Mesmer-Magnus \& Viswesvaran (2005), Cassematis \& Wortley (2013), Cho \& Song (2015), and Chang, Wilding, \& Shin (2017). Based on these findings, the entity is expected to be able to protect whistleblowers so that the mechanisms for preventing and detecting irregularities and fraud can be performed accordingly.

In this research, we also acquired empirical evidence about the indirect effects of knowledge variables (KWB) and subjective norms (SN) through attitudes (ATB) on the intention to conduct whistleblowing. Knowledge and subjective norms show a positive influence on attitudes. The indirect influence model (model 2) is more robust compared to the direct influence model (model 1) of the attitude and subjective norm variables towards the intention to do whistleblowing. This research proves that knowledge and subjective norms form individual attitudes regarding whistleblowing. His knowledge of whistleblowing influences the individual's attitude to the whistleblowing. Individuals who understand the concept of whistleblowing tend to have a positive attitude towards whistleblowing. These results indicate the need to foster awareness about the importance of whistleblowing as a medium for the prevention and detection of fraud. Well-educated individuals have more inclination for reporting indications of irregularities (Pillay et al., 2015). Dissemination of the importance of whistleblowing can be done through education, training, seminars and other activities. By providing knowledge about whistleblowing, individuals will gain additional insight. This additional insight is expected to change the way individuals perceive whistleblowing. Additional insight is also expected to change individual behavior, from having a low level 
of awareness about whistleblowing to become more concerned and aware of the role of whistleblowing in the prevention and detection of fraud. This result is not in line with the research of Chang, Wilding, \& Shin (2017) which shows the direct effect of the knowledge variable on whistleblowing intentions. However, the results of this research support the argument that individuals who know whistleblowing do not necessarily display these actions at the behavioral level (Mesmer-Magnus \& Viswesvaran, 2005).

Meanwhile, subjective norms show a positive influence on attitudes. A person's attitude besides being formed by his knowledge, it turns out also formed by subjective norms that apply in his group. The present group becomes a referent group that has views, aspirations, and opinions that naturally become things agreed upon by members of the group. In the end, the agreed upon things become true-false parameters in the group. Referent groups influence shaping a person's attitude (Trongmateerut \& Sweeney, 2013). Individuals will only act when the action is deemed acceptable by the group. For example, in a group, reporting irregularities are considered as a form of responsibility for work, then employees in the group will tend to have the same perception. So that individuals in it also tend to report indications of irregularities. This is because individuals will only take actions agreed upon by the group. The indirect influence of subjective norms through attitudes toward whistleblowing intentions is stronger than the direct influence. These results reinforce the contingent nature of the attitude variables and support some of the results of previous researches by Ryan (1982), Bock et al. (2005), Albrecht \& Carpenter (2010), and Trongmateerut \& Sweeney (2013).

\section{Conclusion, Limitation, and Suggestions Conclusion}

This research examines TPB as a predictor of intention to conduct whistleblowing. We refer to the study of the theory that observing actual behavior is complex and hard to comprehend, so the most likely thing to observe is the tendency for a behavior to occur. In this case, the behavior is more precisely identified as intention. The intention of whistleblowing is not an easy thing to implement. Whistleblowers are often associated with negative impacts. Therefore, the whistleblowing stops at the level of knowledge, not yet up to actual behavior. A lot of researches explained that there was a reluctance to do whistleblowing. In addition, whistleblowing which is seen as behavior involves a complicated psychological process. Hence, many kinds of research try to observe the intention to do whistleblowing.

We tested attitude variables, subjective norms and behavioral controls as predictors of whistleblowing intentions. We also tested several control variables such as colleague support, organizational support, and fear of retaliation. The findings are there are two robust TPB variables in explaining whistleblowing intentions, namely attitude, and subjective norms. Meanwhile, behavioral control variables did not show a significant effect. Among several control variables studied, only the fear of retaliation variable could be a predictor of whistleblowing intentions.

Furthermore, we also obtain empirical evidence that there is a contingent nature in the attitude variable. The results of this research prove that there are indirect effects of knowledge variables and subjective norms through attitudes toward whistleblowing intentions. Model 1 proves attitude as the strongest predictor. While for model 2, knowledge and subjective norms show a strong influence on attitudes and indirect effects on whistleblowing intentions.

For managerial aspects, this study shows how individual and situational matters are important to encourage employee participation in the term to report wrongdoing. According to the result, management should pay attention to individual aspect such attitudes and subjective norms. Both matters are important regarding fraud prevention and detection activities in the ZZZZ Bank. Employees attitudes toward whistleblowing should construct with positive implication for their personal and organizational in- 


\section{Jurnal Keuangan dan Perbankan}

Volume 23, Issue 1, January 2019: 45-60

sight. It is important because when an employee associated with a positive impact from their participation, the more they intend to blow the whistle. Not only in individually, but also as a part of managerial responsibility, managers need to build compliance environment such as compliance with the code of ethics, operational procedures, performance indicators, etc. It could be a tool to create norms in the office. So, the employee will be more active to participate in reporting wrongdoing. From the organizational aspect, managers should provide assurances for the employee who wants to report a fraud indication. The more employee fell that company gives protection to them, the more their likelihood to blow the whistle.

\section{Limitation and suggestions}

This research has several limitations in terms of variables and samples. The variables tested from previous research only tested some variables that were declared as robust from some literature. Not all personal and situational variables that might be predic- tors were examined in this research. Then, in terms of research samples, they were relatively limited for survey research.

Based on the results of this research, we submit some recommendations for the ZZZZ Bank specifically. First, it is necessary for the management of ZZZZ Bank to establish a certain channel for whistleblowing. This refers to the results of this study which shows a positive attitude and subjective norms that agree to conduct whistleblowing. Second, education and training need to be held such as seminars, workshops, and others related to whistleblowing. These activities are aimed to increase employees' insight into the importance of whistleblowing in supporting efforts to prevent and detect irregularities and fraud. Third, managers should design and manage whistleblowing systems wherever it is possible so that the mechanism of prevention and detection of irregularities can be carried out effectively and efficiently. This includes maintaining the confidentiality of the 'whistle-blower,' ensuring safety, and protection for the reporter from negative impacts.

\section{References}

Ajzen, I. (1991). The theory of planned behavior. Organizational Behavior and Human Decision Processes, 50, $179-211$. https://doi.org/10.1016/0749-5978(91)90020-T

Albrecht, S. L., \& Carpenter, K. E. (2010). Attitudes as predictors of behavior versus behavior intentions: A convergence of research traditions. Sociometry, 39(1), 1-10.

Association of Certified Fraud Examiners. (2018). Report To The Nations 2018 Global Study on Occupational Fraud and Abuse.

Awang, Y., \& Ismail, Z. (2018). Determinants of financial reporting fraud intention among accounting practitioners in the banking sector: Malaysian evidence. International Journal of Ethics and Systems, 34(1), 32-54.

Bobek, D. D., Roberts, R. W., \& Sweeney, J. T. (2007). The social norms of tax compliance: Evidence from Australia, Singapore, and the United States. Journal of Business Ethics, 74(1), 49-64. https://doi.org/10.1007/s10551006-9219-x

Bock, G.-W., Zmud, R. W., Kim, Y.-G., \& Lee, J. (2005). Behavioral intention formation in knowledge sharing: Examining the roles of extrinsic motivators, social-psychological forces, and organizational climate. MIS Quarterly, 29(1), 87-111. https://doi.org/10.2307/25148669

Cassematis, P. G., \& Wortley, R. (2013). Prediction of whistleblowing or non-reporting observation: The Role of personal and situational factors. Journal of Business Ethics, 117(3), 615-634. https://doi.org/10.1007/s10551012-1548-3 


\title{
Theory of planned behavior and whistleblowing intention
}

\author{
Tarjo, Prasetyono, Anang Suwito, Ifa Diah Aprillia, Greska Redielano Ramadan
}

Chang, Y., Wilding, M., \& Shin, M. C. (2017). Determinants of whistleblowing intention: Evidence from the South Korean Government. Public Performance and Management Review, 40(4), 676-700. https://doi.org/10.1080/ 15309576.2017.1318761

Cho, Y. J., \& Song, H. J. (2015). Determinants of whistleblowing within government agencies. Public Personnel Management, 44(4), 450-472. https://doi.org/10.1177/0091026015603206

Christophersen, T., \& Konradt, U. (2011). Reliability, validity, and sensitivity of a single-item measure of online store usability. International Journal of Human-Computer Studies, 69(4), 269-280. https://doi.org/10.1016/ j.ijhcs.2010.10.005

Cialdini, R. B., \& Goldstein, N. J. (2004). Social influence: Compliance and conformity. Annual Review of Psychology, 55(1), 591-621. https://doi.org/10.1146/annurev.psych.55.090902.142015

Erikson, K., \& Fallan, L. (1996). Tax knowledge and attitudes towards taxation; A report on a quasi-experiment. Journal of Economic Psychology, 17(3), 387-402. Retrieved from http://proquest.umi.com/ pqdweb?did=39712230\&Fmt=7\&clientId=25620\&RQT $=309 \& \mathrm{VName}=\mathrm{PQD}$

Feldman, Y., \& Lobel, O. (2007). Behavioral versus institutional antecedents of decentralized enforcement in organizations: An experimental approach. Regulation \& Governance, 2(2), 165-192. https://doi.org/10.2139/ ssrn. 1031853

Gundlach, M. J., Douglas, S. C., \& Martinko, M. J. (2003). The decision to blow the whistle: A social information processing framework. Academy of Management Review, 28(1), 107-123. https://doi.org/10.5465/ AMR.2003.8925239

Hwang, D., Staley, B., Chen, Y. Te, \& Lan, J. S. (2008). Confucian culture and whistle-blowing by professional accountants: An exploratory study. Managerial Auditing Journal, 23(5), 504-526. https://doi.org/10.1108/ 02686900810875316

Krosnick, J. A., Narayan, S., \& Smith, W. R. (1996). Satisficing in surveys: Initial evidence. New Directions for Evaluation, 70, 29-44.

Latan, H., Jabbour, C. J. C., \& Jabbour, A. B. L. de S. (2016). Ethical decision-making theory: An integrated approach. Journal of Business Ethics, 139(4), 755-776. https://doi.org/10.1007/s10551-015-2886-8

Lewis, W., Agarwal, R., \& Sambamurthy, V. (2014). Sources of influence on beliefs about information technology use: An empirical study of knowledge workers. MIS Quarterly, 24(4), 665-694. https://doi.org/10.2307/3250951

Lozano, L. M., García-Cueto, E., \& Muñiz, J. (2008). Effect of the number of response categories on the reliability and validity of rating scales. Methodology, 4(2), 73-79. https://doi.org/10.1027/1614-2241.4.2.73

Madden, T. J., Ellen, P. S., \& Ajzen, I. (1992). A comparison of the theory of planned behavior and the theory of reasoned action. Personality and Social Psychology Bulletin, 18(1), 3-9.

Mesmer-Magnus, J. R., \& Viswesvaran, C. (2005). Whistleblowing in organizations: An examination of correlates of whistleblowing intentions, actions, and retaliation. Journal of Business Ethics, 62(3), 277-297. https://doi.org/ 10.1007/s10551-005-0849-1

Miceli, M. P., \& Near, J. P. (1988). Individual and situational correlates of whistleblowing. Personnel Psychology, 41(2), 267-281. https://doi.org/10.1111/j.1744-6570.1988.tb02385.x

Near, J. P., \& Miceli, M. P. (1985). Organizational dissidence: The case of whistle-blowing. Journal of Business Ethics, 4(1), 1-16. https://doi.org/10.1007/BF00382668

Park, H., \& Blenkinsopp, J. (2009). Whistleblowing as planned behavior-A survey of South Korean police officers. Journal of Business Ethics, 85(4), 545-556. https://doi.org/10.1007/s10551-008-9788-y

Pillay, S., Ramphul, N., Dorasamy, N., \& Meyer, D. (2015). Predictors of whistle-blowing intentions: An analysis of multi-level variables. Administration and Society, 50(2), 186-216. https://doi.org/10.1177/0095399715581621

Preacher, K. J., \& Hayes, A. F. (2004). SPSS and SAS procedures for estimating indirect effects in simple mediation models. Behavior Research Methods, Instruments \& Computers, 36(4), 717-731. https://doi.org/10.3758/ BF03206553 


\section{Jurnal Keuangan dan Perbankan}

Volume 23, Issue 1, January 2019: 45-60

Richardson, B. K., Wang, Z., \& Hall, C. A. (2012). Blowing the whistle against Greek hazing: The theory of reasoned action as a framework for reporting intentions. Communication Studies, 63(2), 172-193. https://doi.org/10.1080/ 10510974.2011.624396

Ryan, M. J. (1982). Behavioral Intention formation: The Interdependency of attitudinal and social influence variables. Journal of Consumer Research, 9(3), 263. https://doi.org/10.1086/208922

Trongmateerut, P., \& Sweeney, J. T. (2013). The influence of subjective norms on whistle-blowing: A cross-cultural investigation. J Bus Ethics, 112(3) 437-451. https://doi.org/10.1007/s10551-012-1270-1

Weijters, B., Cabooter, E., \& Schillewaert, N. (2010). The effect of rating scale format on response styles: The number of response categories and response category labels. International Journal of Research in Marketing, 27(3), 236247. https://doi.org/10.1016/j.ijresmar.2010.02.004 